\title{
Modifying Soil Chemistry to Enhance Heathland Recreation: A Use for Sulphur Captured During Oil Refining
}

\author{
lain Green ${ }^{1 *}$, Damian Evans ${ }^{2}$ and Anita Diaz ${ }^{1}$ \\ ${ }^{1}$ Department of Life and Environmental Sciences, Bournemouth University, Talbot Campus, \\ Fern Barrow, Poole, Dorset, BH125BB, United Kingdom. \\ ${ }^{2}$ Department of Archaeology, Anthropology and Forensic Science, Bournemouth University, \\ Talbot Campus, Fern Barrow, Poole, Dorset, BH125BB, United Kingdom.
}

Authors' contributions

This work was carried out in collaboration between all authors. Authors IG and AD co-designed the study. Author DE coordinated data collection and sample processing. Author IG performed the statistical analysis and wrote the first draft of results and discussion sections. Author AD wrote the first draft of the introduction and methods. All authors read and approved the final manuscript.

Article Information

DOI: $10.9734 / / J P S S / 2015 / 14519$

Editor(s):

(1) Eliana L. Tassi, Institute of Ecosystem Studies, National Research Council (CNR), Italy.

(2) Junhong Bai, School of Environment, Beijing Normal University, Beijing, China.

Reviewers:

(1) Anonymous, South Africa.

(2) Laura Antonela Iturri, Institute for Earth and Environmental Sciences of La Pampa of The National Council for Research and

Technology and Faculty of Natural Sciences of The National University of La Pampa, Argentina.

(3) Anonymous, India.

Complete Peer review History: http://www.sciencedomain.org/review-history.php?iid=957\&id=24\&aid=8531

Short Research Article

Received $4^{\text {th }}$ October 2014

Accepted $27^{\text {th }}$ February 2015

Published 19 ${ }^{\text {th }}$ March 2015

\section{ABSTRACT}

The overall aim of this paper is to evaluate potential new modifications to methods for re-creating heathland habitats. Heathlands need acidic soils so the specific objectives are to evaluate the effectiveness of a new method for heathland re-creation by soil acidification using a sulphur soil amendment and to explore the benefits for re-creation of applying a soil stripping treatment in conjunction with soil acidification. A new source of sulphur was recovered from oil refinery towers and applied over agricultural sites covering a total of 13 ha on Trehill Farm, Marloes, Pembrokeshire, Wales, UK in 2004. In the summer of 2011 we compared soil chemistry and plant communities on sites subjected to different sulphur treatments (sulphur applied to the existing soil 
surface and sulphur applied after top soil had been stripped) with those on an adjacent untreated control and on a nearby established heathland. Each of the four treatment sites and the control and heath site was surveyed using 10 random locations measuring $4 \mathrm{~m} \times 4 \mathrm{~m}$. The total above ground $\%$ cover was measured for each plant species and a bulk soil sample was taken in a 'W' shape from within each $4 \mathrm{~m} \times 4 \mathrm{~m}$ quadrat. $\mathrm{pH}$ and all chemical parameters of the soil showed highly significant differences amongst the sampled sites ( $P>0.01$ in all cases) and produced even greater abundance of ericaceous species on some of the treated sites than occurred in the established heath. However, soil stripping had no significant additional effect on either edaphic factors or plant species abundances. Sulphur recovered from oil refinery is a potentially useful tool in heathland recreation, but soil stripping prior to sulphur amendment did not enhance success. We propose that sulphur application drives success through increasing $\mathrm{H}^{+}$toxicity reducing the availability of base cations and creating Fe-induced Mn deficiency in plants.

Keywords: Heathland; acidification; plant community; restoration; creation, fuel; wood and grazing lands.

\section{INTRODUCTION}

Lowland heathland is one of the world's rarest and most fragmented habitats and occurs predominately on acidic soils on the Atlantic seaboard of Europe [1]. It is a low-growing ericaceous scrub community with a large proportion of specialist species (Fig. 1). It has predominantly arisen through, and is maintained largely by, centuries of anthropogenic activities such as livestock grazing and collection of wood fuel, building materials and bedding [2,3]. However, widespread industrialisation, decline of traditional farming practices and spread of urban development has created huge losses over the last two centuries [4-6].

As a result of this loss, the re-creation of lowland heath is an important aspect of heathland conservation and there has been considerable research effort put into devising methods for recreating heathland on land where it has been lost due to agricultural intensification [7-10]. As heathlands are special ecosystems dependent on acidic, nutrient poor soils, all methods seek to reverse the key edaphic changes effected during agricultural improvement (i.e. increased soil $\mathrm{pH}$ and nutrient availability) so that ericaceous species are not out-competed by mesotrophic grasses [11,12]. This can be achieved by physically removing the improved topsoil $[13,14]$ or by chemically amending it to reduce $\mathrm{pH}$ and macronutrient concentrations [15,16]. Usually only one of these approaches is used and the acidification agent that has emerged as particularly effective is elemental sulphur in the form of the agricultural fertiliser Brimstone 90 $[17,18]$. However both soil stripping and Brimstone 90 application are expensive techniques to use on a large scale. Furthermore, each has an important limitation when used alone; soil stripping results in $\mathrm{pH}$ still being high and acidification with sulphur results in increased availability of phosphate [18].

In this article, we consider two issues viz the effectiveness for re-creating heathlandsupporting soils of i) Using an alternative, cheaper source of sulphur for soil acidification and ii) Combining a soil stripping treatment together with a sulphur soil acidification treatments were evaluated.

\section{METHODOLOGY}

\subsection{Site Description}

The study was conducted on Trehill Farm, which is located on the Marloes Peninsula, Pembrokeshire (O.S. Ref: SM766082). The soils are boulder clay surface-water gley soils (cambicstagnogley and stagno-humicgley) that have imperfect drainage and so are subject to seasonal water-logging [19]. Historic records of past land use in the coastal strip of the Trehill farm area prior to the mid- $20^{\text {th }}$ century are limited, but indicate that it was largely heathland, used for grazing cattle. The farm was purchased by the National Trust, a UK conservation charity, in 1941. By this time, as elsewhere across Europe, increased mechanisation and intensification of agriculture had resulted in this land having been ploughed and converted to cereal production, particularly triticale and barley. Growing these crops required soil modification by liming to reduce soil acidity and substantial and sustained input of fertilisers, particularly as these crops were under sown with rye grass to provide forage for sheep during the winter months. 


\subsection{Experimental Treatments}

In the 1990s, the National Trust embarked on a heathland re-creation plan for a total of 13 ha of the coastal part of the farm. Achieving this required either modification or removal of the improved soil so that edaphic conditions were suitable for supporting acidophilus heathland plant species rather than mesotrophic grassland species. Some soil stripping was carried out in some areas (areas B E and F; Fig. 2) to depth of between 20 and $30 \mathrm{~cm}$ in September 2003. However, it was decided that acidification with sulphur would be the main treatment applied throughout the farm, including on areas that had already been soil stripped. A novel source of sulphur was used as the high cost of processed, agricultural grade elemental sulphur limited its practical applicability for large scale use. The new source was sulphur recovered from oil refinery towers and was donated by ChevronTexaco's Pembroke refinery. The sulphur was collected in the usual way as a hot liquid directly from the plant's sulphur recovery unit, which was discharged onto a bunded hard standing in a corner of the refinery, where it cooled and solidified. This was then broken down into a powder using a combination of a 1.5 metre, rideon vibrating roller and JCB. This processing resulted in $100 \mathrm{t}$ of sulphur fragments that varied in size from powder to nuggets measuring a few $\mathrm{cm}$ across. This variation is an inherent consequence of the production method and was considered likely to be advantageous as the larger fragments would be able to provide a slowrelease effect, which would perhaps help to maintain low $\mathrm{pH}$ into the long-term.

In the spring of 2004, the sulphur was applied using a conventional lime-spreader at a rate of about $4 \mathrm{t} \mathrm{ha}^{-1}$ across most of the sites (although up to $8 \mathrm{tha}^{-1}$ was applied in some patches that supported particularly strong growth of mesotrophic grasses, such as the sown rye grass). The sulphur spreading work was completed within 1 day. The long absence of ericaceous species from this site meant that it was deemed necessary to introduce a source of heather seed. Seed was collected from a nearby site by cutting heather brash in late October 2004 using a double-chop forage harvester, which could cut and shred the woody material containing the seed and blow it into $14 \mathrm{t}$ trailers drawn alongside. A total of 18 trailer loads were taken to Trehill and spread using a muck spreader on same day as harvested to produce a $50 \%$ cover of heath mulch on all the areas where sulphur has been applied.

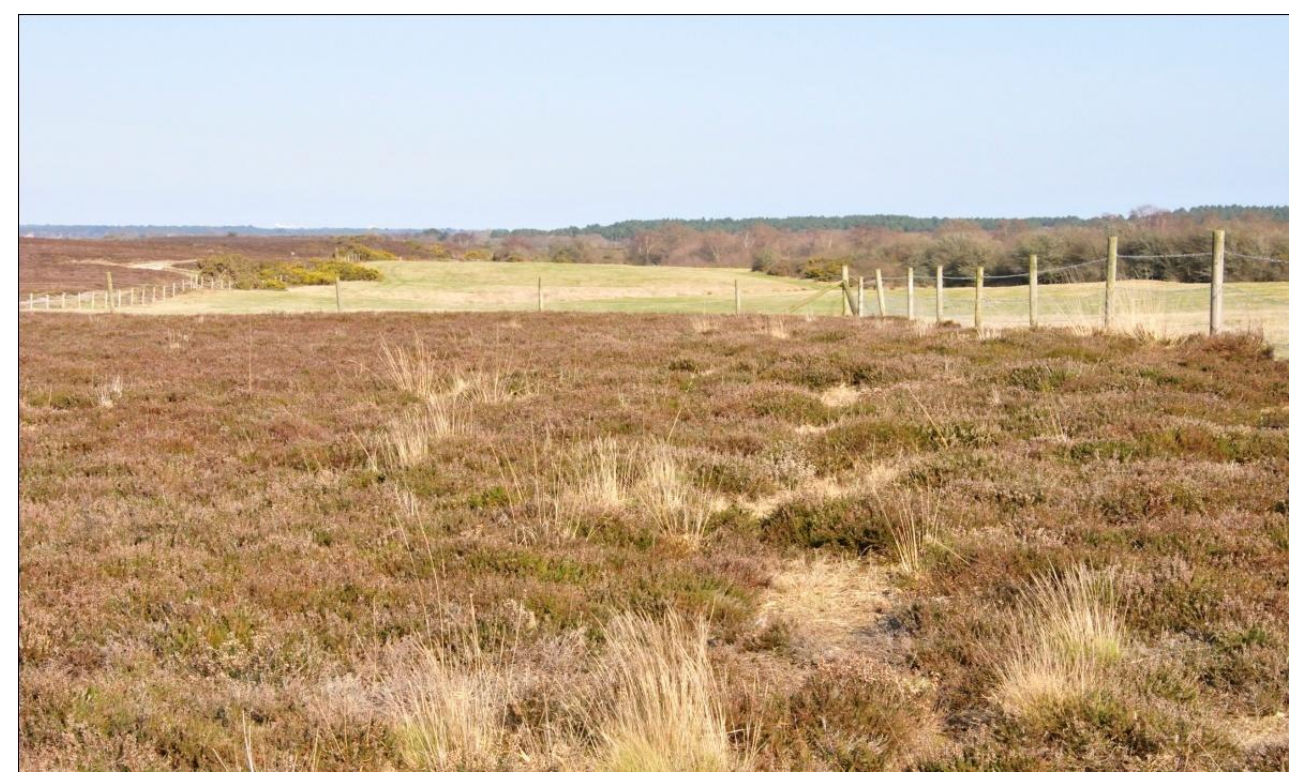

Fig. 1. Lowland heath typically has a plant community dominated by dwarf ericaceous shrubs, specifically Calluna vulgaris and Erica spp. (foreground). It is considered Europe's most endangered habitat and conversion into mesotrophic grassland (as is seen in the background) is a significant cause of heathland loss 


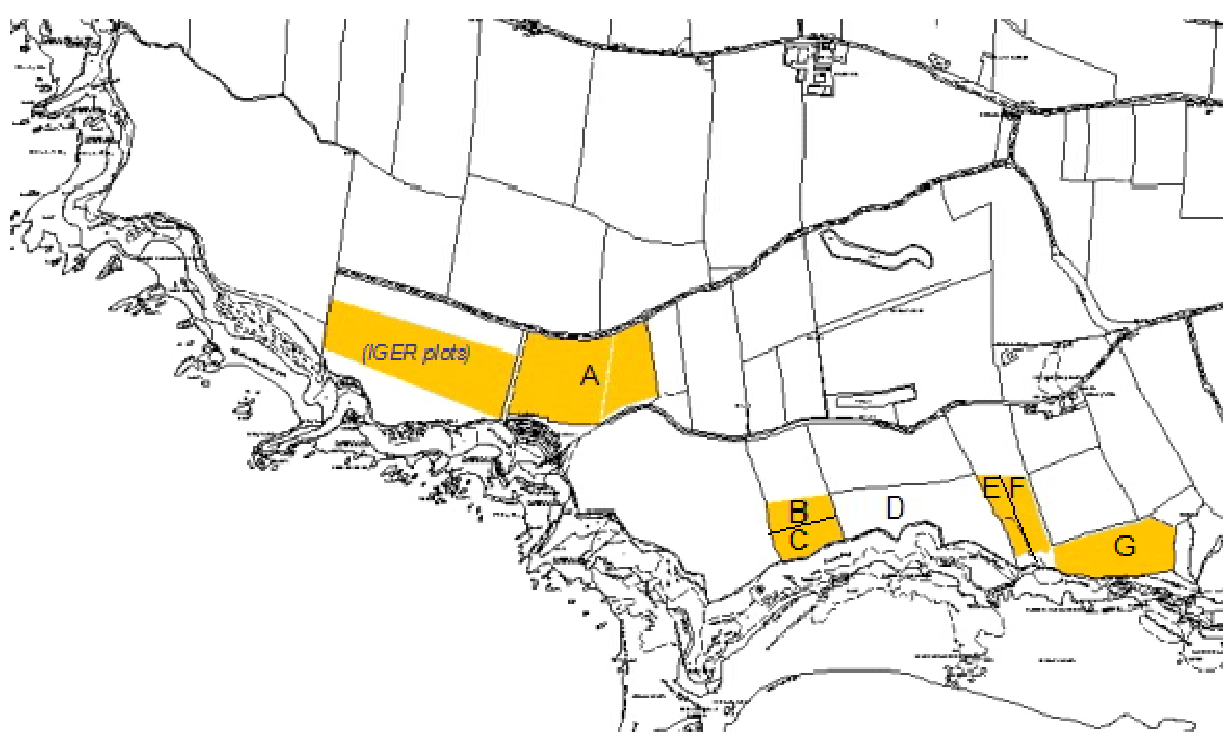

Fig. 2. Area of sulphur application and site locations on Trehill Farm, Pembrokeshire. Areas of sulphur application are indicated in yellow. Areas A, B, F and G received sulphur without soil stripping; sites $B, E$ and $F$ received sulphur with soil stripping, site $D$ is a control area with neither sulphur application nor soil stripping treatment and Heath (not shown) is the nearest target heathland (at Wooltack Point)

A nearby, long established heathland $2 \mathrm{~km}$ north west of Trehill farm at Wooltack Point (Latitude: $51^{\circ} 44.20^{\prime}$ N., Longitude: $005^{\circ} 14.83^{\prime}$ W., OS Reference: SM 759 092) was used as target community against which to compare the soil chemistry and vegetation community on the treated sites.

\subsection{Site Data Collection}

In the summer of 2011, a survey was carried out of the soils and plant communities created on four of the sulphur amended sites at Trehill (sites $A, B, F$ and $G$ ), which were compared to a control site where no sulphur had been added (site D) and the long established heathland at Wooltack Point. Sites A, B, F and G were chosen to enable comparison between sites where soil was stripped in addition to sulphur application (Table 1).

Each of the treatment sites and the control and heath site was surveyed using ten random locations measuring $4 \mathrm{~m} \times 4 \mathrm{~m}$. In each of these locations, the total above ground \% cover was recorded for each plant species by visual estimation [20] and the soils sampled from the $A_{p}$ horizon $(10-15 \mathrm{~cm})$ by the taking of ten subsamples in a 'W' shape. Soil samples from each location were bulked together, yielding ten measurements of the plant community and ten soil samples for each site sampled.

\subsection{Soil Analyses}

Soil analysis was carried out on the fine earth fraction. Soil $\mathrm{pH}$ was determined in a 2.5:1 suspension of water to soil. The extractable concentrations of $\mathrm{Ca}, \mathrm{K}$, and $\mathrm{Mg}$ in soil were determined by shaking $10 \mathrm{~g}$ of soil in $50 \mathrm{ml}$ of 1 $\mathrm{M}$ ammonium nitrate for $30 \mathrm{~min}$ [21]. The extractable concentration of $\mathrm{Fe}$ was determined via extraction from $10 \mathrm{~g}$ of soil with $50 \mathrm{ml}$ of 0.05 $M$ EDTA disodium salt after shaking for $1 \mathrm{~h}$ at $20^{\circ} \mathrm{C}$. The exchangeable and easily reducible $\mathrm{Mn}$ concentration was determined by extraction in $0.2 \% \mathrm{w} / \mathrm{v}$ quinol $/ 1 \mathrm{M}$ ammonium acetate from 10 $\mathrm{g}$ of soil. Soil and extract and were shaken for 30 min and allowed to stand for $6 \mathrm{~h}$ (with frequent, periodic shaking) [21]. Extractable Al concentrations in the soil were determined by extraction with Morgan's reagent (1.25 M ammonium acetate acidified to $\mathrm{pH} 4.8$ with acetic acid). A suspension was formed from $10 \mathrm{~g}$ of soil and $50 \mathrm{ml}$ of Morgan's reagent, which was left to stand for $2 \mathrm{~h}$ before being filtered and made up to a final volume of $100 \mathrm{ml}$ [22]. Sulphate concentration in soils was ascertained from the extractable concentration of $\mathrm{S}$, which in turn was determined via the extraction of $S$ from $10 \mathrm{~g}$ of soil by $50 \mathrm{ml}$ of $0.016 \mathrm{M}$ potassium dihydrogen 
orthophosphate [23]. Plant available phosphorous was determined by shaking $0.5 \mathrm{~g}$ of soil with $100 \mathrm{ml}$ of sodium bicarbonate $(\mathrm{pH} \mathrm{8.5)}$ for $30 \mathrm{~min}$ at temperature of $20^{\circ} \mathrm{C}$ [24]. Concentrations of elements in extracts were determined by ICP-OES, whilst phosphorous concentration in extracts was determined using the molybdenum blue method [25].

\subsection{Data Analyses}

Preliminary screening of the data sets for compliance with the assumptions of parametric statistical tests revealed that the majority of data sets failed to meet these assumptions. Accordingly, robust methods of statistical analyses were used throughout. For one-way comparisons, Welch's F-ratio was used along with the Games-Howell post hoc test. Correlations between variables were determined by Spearman's rank order method. No Erica cinerea or Calluna vulgaris plants were found growing in the control site and this site was not included in the one-way comparisons for these two species as Welch's F-ratio could not be calculated. All statistical analyses were conducted using SPSS vs. 19 and significance was determined by $P<0.05$ in all instances.

\section{RESULTS}

\subsection{Soil Parameters}

All measured soil chemical parameters demonstrated highly significant differences amongst the sampled sites (Table 2). In both T3 and T4, sulphur treatment lowered soil $\mathrm{pH}$ compared to the control (T1) and target heath (T2), with the exception that one T4 site (B) had a $\mathrm{pH}$ that did not differ significantly from the heath soil. The base cation and plant macro nutrient $\mathrm{K}$ was significantly more available in the soils of the heath than in the other sites, including the control (T2). Extractable $\mathrm{K}$ concentration did not differ among one T3 site $(A)$, one T4 site $(B)$ and the control, but the other T1 site $(G)$ and T4 site (F) had significantly lower $\mathrm{K}$ concentrations. The other two important base cations are $\mathrm{Ca}$ and $\mathrm{Mg}$. Extractable $\mathrm{Ca}$ concentrations differed significantly from the control site and heath (T2) in both sites of T4 and one T3 site $(G)$. T3 site $A$, the heath and control showed no significant difference in $\mathrm{Ca}$ concentration. The extractable concentration of $\mathrm{Mg}$ was markedly lower in the T3 and T4 treatments than in the heath and the control, which did not differ significantly from each other.

Extractable phosphate and $\mathrm{Fe}$ concentrations increased in the sulphur treatments T3 and T4 sites compared to the control and heath sites. The lowest phosphate concentration was found in the heath and both T3 and T4 sulphur treatments resulted in a marked increase in extractable phosphate. Both the heath and control differed significantly from the T3 and T4 sulphur treatments, whilst no significant differences were found between the T3 and T4 treatments. $\mathrm{Al}$ and $\mathrm{Mn}$ are potentially toxic cations [26]. Extractable concentrations of both these elements were high in the soil from the heath. Extractable Mn concentrations were also high in the control. In both T3 and T4, elemental sulphur application tended to lower the concentration of $\mathrm{Al}$ and, particularly, $\mathrm{Mn}$. However, one T3 site (A) showed no difference in $\mathrm{Al}$ concentration and one T4 site (B) exhibited no significant difference in $\mathrm{Mn}$ concentration when compared to the heath.

Table 1. Details of the experimental sites and treatments used to restore lowland heath

\begin{tabular}{|c|c|c|c|c|}
\hline \multirow[t]{2}{*}{ Site } & \multicolumn{3}{|c|}{ Treatment } & \multirow[t]{2}{*}{ Notes } \\
\hline & Code & $\begin{array}{l}\text { Soil stripping } \\
(20-30 \mathrm{~cm})\end{array}$ & $\begin{array}{l}\text { Elemental S } \\
\left(4 \mathrm{t} \mathrm{ha}^{-1}\right)\end{array}$ & \\
\hline D & T1 & No & No & Control site with no treatments \\
\hline Heath & $\mathrm{T} 2$ & No & No & Target heathland \\
\hline A & T3 & No & Yes & $\begin{array}{l}\text { S applied up to } 8 \mathrm{t} \mathrm{ha}^{-1} \text { in patches. } \\
\text { See method. }\end{array}$ \\
\hline$G$ & T3 & No & Yes & $\begin{array}{l}\text { S applied up to } 8 \mathrm{t} \mathrm{ha}^{-1} \text { in patches. } \\
\text { See method. }\end{array}$ \\
\hline B & $\mathrm{T} 4$ & Yes & Yes & $\begin{array}{l}\text { S applied up to } 8 \mathrm{t} \mathrm{ha}^{-1} \text { in patches. } \\
\text { See method. }\end{array}$ \\
\hline $\mathrm{F}$ & $\mathrm{T} 4$ & Yes & Yes & $\begin{array}{l}\text { S applied up to } 8 \mathrm{t} \mathrm{ha}^{-1} \text { in patches. } \\
\text { See method. }\end{array}$ \\
\hline
\end{tabular}


Table 2. Soil pH and extractable concentrations ( $\mathrm{mg} \mathrm{kg}^{-1}$; mean $\left.\pm 1 \mathrm{SE}\right)$ of selected elements, sulphate and phosphate obtained from the soils of an untreated control site (T1), an adjacent target heath (T2), 2 sites subject to only elemental sulphur application (T3) and 2 sites subject to soil stripping and elemental sulphur (T4)

\begin{tabular}{|c|c|c|c|c|c|c|c|c|c|}
\hline \multirow[t]{2}{*}{ Treatments } & \multicolumn{9}{|c|}{ Soil properties } \\
\hline & $\mathrm{pH}$ & $\mathrm{SO}_{4}{ }^{2-}$ & $\mathrm{PO}_{4}{ }^{3-}$ & $\mathbf{C a}$ & $\mathrm{Mg}$ & $\mathbf{K}$ & Mn & $\mathrm{Fe}$ & $\mathrm{Al}$ \\
\hline T1 (Control) & $5.94 \pm 0.08$ & $6.5 \pm 0.4$ & $22.4 \pm 3.0$ & $323 \pm 69.6$ & $197 \pm 6.4$ & $159 \pm 13.5$ & $22.2 \pm 1.52$ & $396 \pm 43$ & $5103 \pm 244$ \\
\hline T2 (Heath) & $5.41 \pm 0.03$ & $9.1 \pm 0.6$ & $9.0 \pm 0.5$ & $193 \pm 8.4$ & $241 \pm 6.6$ & $211 \pm 6.6$ & $23.8 \pm 2.5$ & $498 \pm 39$ & $7757 \pm 328$ \\
\hline T3 (Site A) & $4.50 \pm 0.06$ & $68.2 \pm 11.1$ & $51.7 \pm 3.5$ & $131 \pm 41.5$ & $31.0 \pm 2.9$ & $107 \pm 10.5$ & $3.99 \pm 0.81$ & $2073 \pm 159$ & $8092 \pm 308$ \\
\hline T3 (Site G) & $4.60 \pm 0.11$ & $37.8 \pm 5.5$ & $54.2 \pm 6.7$ & $46.0 \pm 15.6$ & $48.3 \pm 20.9$ & $88.7 \pm 14.4$ & $8.54 \pm 1.72$ & $999 \pm 153$ & $4447 \pm 230$ \\
\hline T4 (Site B) & $4.95 \pm 0.15$ & $37.3 \pm 6.6$ & $66.6 \pm 10.8$ & $64.0 \pm 30.9$ & $53.6 \pm 14.6$ & $117 \pm 9.7$ & $19.9 \pm 3.55$ & $943 \pm 174$ & $6314 \pm 410$ \\
\hline T4 (Site F) & $4.13 \pm 0.15$ & $66.3 \pm 8.2$ & $93.1 \pm 8.3$ & $32.5 \pm 15.1$ & $25.4 \pm 5.2$ & $85.3 \pm 9.9$ & $9.33 \pm 1.46$ & $943 \pm 174$ & $6314 \pm 410$ \\
\hline Welch's F' & 113 & 26.2 & 59.8 & 25.0 & 240 & 31.4 & 24.9 & 28.2 & 24.5 \\
\hline & $5,24.0$ & $5,23.0$ & $5,21.4$ & $5,23.9$ & $5,24.0$ & $5,24.9$ & $5,24.3$ & $5,23.9$ & $5,25.0$ \\
\hline Signif. $(P)$ & $>0.01$ & $>0.01$ & $>0.01$ & $>0.01$ & $>0.01$ & $>0.01$ & $>0.01$ & $>0.01$ & $>0.01$ \\
\hline
\end{tabular}




\subsection{Plant Cover}

Significant differences were found amongst the treatments for the cover of Erica cinerea, Calluna vulgaris, Agrostis capillaris, Holcus lanatus and Trifolium repens, but not for Plantago lanceolata (Table 3). The typical heath species E. cinerea displayed significantly greater cover in one T3 site $(G)$ and one T4 site $(F)$ than in the other T3 site (A) and T4 site (B), but no site was significantly different from the heath site in terms of $E$. Cinerea cover. The other species typical of heath, $C$. vulgaris, showed broadly the same pattern, although one T3 site $(G)$ had significantly greater cover than other T3 site $(A)$, one T4 site (B) and the heath (T2).

Agrostis capillaris cover was significantly decreased in the sulphur treatments T3 and T4 compared to the control and $A$. capillaris cover was only significantly lower than in the heath in site A of T3. Holcus lanatus cover was greatest in the T4 sites, but only one T4 site (B) exhibited significantly greater cover than the heath (T2) or control (T1). Cover of $T$. repens was similar in all sites except site A of T3; indeed, the only significant difference found was between this site and the heath.

\section{Table 3. Percentage cover (mean \pm 1SE) of selected plant species growing in an untreated control site (T1), an adjacent target heath (T2), 2 sites subject to only elemental sulphur application (T3) and 2 sites subject to soil stripping and elemental sulphur (T4)}

\begin{tabular}{lllllll}
\hline Treatments & \multicolumn{5}{c}{ Plant cover } \\
\cline { 2 - 6 } & E. cinerea & C. vulgaris & A. Capillaris & $\boldsymbol{H}$. lanatus & T. repens & $\boldsymbol{P}$. lanceolata \\
\hline T1 (Control) & 0 & 0 & $40.5 \pm 4.2$ & $12.4 \pm 5.3$ & $15.5 \pm 2.8$ & $2.3 \pm 0.7$ \\
T2 (Heath) & $5.1 \pm 1.5$ & $4.4 \pm 1.2$ & $25.5 \pm 4.6$ & $15.0 \pm 2.4$ & $4.6 \pm 0.9$ & $5.5 \pm 1.0$ \\
T3 (Site A) & $1.2 \pm 0.7$ & $2.8 \pm 0.8$ & $4.8 \pm 1.2$ & $12.4 \pm 5.3$ & $0.2 \pm 0.2$ & $1.8 \pm 0.9$ \\
T3 (Site G) & $7.1 \pm 1.2$ & $11.7 \pm 2.0$ & $16.7 \pm 2.3$ & $15.0 \pm 2.7$ & $3.1 \pm 1.2$ & $3.9 \pm 1.0$ \\
T4 (Site B) & $0.8 \pm 0.3$ & $2.6 \pm 1.0$ & $13.4 \pm 2.8$ & $38.0 \pm 4.3$ & $5.8 \pm 1.9$ & $4.1 \pm 1.1$ \\
T4 (Site F) & $7.3 \pm 1.4$ & $8.1 \pm 2.1$ & $21.5 \pm 3.6$ & $25.0 \pm 3.1$ & $2.4 \pm 0.9$ & $3.2 \pm 1.0$ \\
Welch's F & 11.24 & 5.17 & 18.4 & 5.68 & 7.98 & 1.96 \\
d.f. & $4,20.4$ & $4,22.0$ & $5,23.9$ & $5,25.0$ & $5,22.2$ & $5,25.1$ \\
Signif. (P) & $<0.001$ & 0.004 & $<0.001$ & 0.001 & $<0.001$ & 0.12 \\
\hline
\end{tabular}

Table 4. Correlations between soil chemical properties

\begin{tabular}{|c|c|c|c|c|c|c|c|c|}
\hline & $\mathrm{pH}$ & $\mathrm{SO}_{4}{ }^{2-}$ & $\mathrm{PO}_{4}{ }^{3-}$ & $\mathrm{K}$ & $\mathrm{Ca}$ & Mg & Al & Mn \\
\hline $\mathrm{SO}_{4}^{2-}$ & $-0.91^{* * *}$ & - & $0.74^{* * *}$ & $-0.72^{\star \star \star}$ & $-0.32^{* \star *}$ & $-0.82^{\star \star *}$ & -0.10 & $-0.73^{* * *}$ \\
\hline $\mathrm{PO}_{4}^{3-}$ & $-0.72^{* * *}$ & $0.74^{* * *}$ & - & $-0.74^{* * *}$ & $-0.68^{* * *}$ & $-0.86^{* * *}$ & $-0.30^{*}$ & $-0.56^{\star * *}$ \\
\hline $\mathrm{K}$ & $0.76^{\star * *}$ & $-0.72^{* * *}$ & $-0.74^{* * *}$ & - & $0.69^{* * *}$ & $0.89^{* * *}$ & $0.55^{\star * *}$ & $0.67^{* * *}$ \\
\hline $\mathrm{Ca}$ & $0.58^{* * *}$ & $-0.63^{* * *}$ & $-0.68^{* *}$ & $0.69^{* * *}$ & - & $0.67^{* * *}$ & $0.28^{*}$ & $0.48^{* * *}$ \\
\hline $\mathrm{Mg}$ & $0.84^{\star \star *}$ & $-0.82^{\star \star *}$ & $-0.86^{\star * *}$ & $0.89^{* * *}$ & $0.67^{* * *}$ & - & $0.38^{* *}$ & $0.72^{\text {*** }}$ \\
\hline $\mathrm{Al}$ & 0.20 & -0.10 & $-0.30^{*}$ & $0.55^{\star \star *}$ & $0.28^{*}$ & $0.38^{* *}$ & - & 0.12 \\
\hline $\mathrm{Mn}$ & $0.74^{* * *}$ & $-0.73^{\star * *}$ & $-0.56^{\star * *}$ & $0.67^{* * *}$ & $0.48^{* * *}$ & $0.72^{\star * *}$ & 0.12 & - \\
\hline $\mathrm{Fe}$ & $-0.76^{* * *}$ & $0.84^{* * *}$ & $0.63^{* * *}$ & $-0.66^{\star * *}$ & $-0.55^{\star * *}$ & $-.72^{* * *}$ & -0.03 & $-0.81^{\star * *}$ \\
\hline
\end{tabular}

Table 5. Correlation coefficients between \% plant cover and soil chemical properties

\begin{tabular}{lllllll}
\hline & C. vulgaris & E. cinerea & A. capillaris & H. lanatus & T. repens & P. lanceolata \\
\hline $\mathrm{pH}$ & $-0.56^{* * *}$ & $-0.53^{* * *}$ & $0.49^{* * *}$ & -0.05 & 0.13 & 0.19 \\
$\mathrm{SO}_{4}{ }^{2-}$ & $0.42^{* *}$ & $0.34^{* *}$ & $-0.46^{* * *}$ & 0.08 & -0.18 & -0.22 \\
$\mathrm{PO}_{4}{ }^{3-}$ & $0.29^{*}$ & 0.21 & $-0.27^{*}$ & 0.21 & -0.13 & $-0.25^{*}$ \\
$\mathrm{~K}_{\mathrm{Ca}}$ & $-0.36^{* *}$ & $-0.28^{*}$ & 0.24 & -0.08 & 0.21 & 0.19 \\
$\mathrm{Mg}$ & $-0.32^{*}$ & $-0.29^{*}$ & 0.13 & -0.22 & 0.01 & 0.09 \\
$\mathrm{Al}$ & $-0.39^{* *}$ & $-0.30^{*}$ & $0.32^{*}$ & -0.11 & 0.15 & 0.22 \\
$\mathrm{Mn}$ & -0.22 & -0.25 & $-0.27^{*}$ & -0.11 & -0.7 & -0.001 \\
$\mathrm{Fe}$ & -0.29 & -0.24 & $0.47^{* * *}$ & 0.14 & $0.31^{*}$ & $0.25^{*}$ \\
\hline \multicolumn{2}{r}{} & 0.24 & $-0.48^{* * *}$ & -0.10 & -0.22 & $-0.26^{*}$ \\
\hline
\end{tabular}




\subsection{Correlations between Soil Parameters and Plant Species Cover}

With the exception of $\mathrm{Al}$, Soil parameters were strongly correlated with soil pH (Table 4). The $\mathrm{pH}$ of the soil was also the parameter exhibiting the strongest correlation with the cover of $C$. vulgaris and $E$. cinerea (Table 5). In addition to $\mathrm{pH}, E$. cinerea cover was also correlated with extractable $\mathrm{K}, \mathrm{Ca}, \mathrm{Mg}$ and $\mathrm{SO}_{4}{ }^{2-}$. Calluna vulgaris cover was correlated with $\mathrm{P}, \mathrm{K}, \mathrm{Ca}$ and $\mathrm{SO}_{4}^{2-}$. Consequently, $\mathrm{pH}$ appeared to the prime driver of differences in both the soil chemistry and positive changes in the plant community.

Cover of $A$. capillaris was significantly correlated with soil $\mathrm{pH}$ and with the extractable concentrations of $\mathrm{Al}, \mathrm{Mn}$ and $\mathrm{Fe}$. Cover of Trifolium repens and $P$. lanceolata were also positively correlated with $\mathrm{Mn}$ and $P$. lanceolata was additionally negatively correlated with $\mathrm{Fe}$. Consequently, $\mathrm{Mn}$ and/or Fe showed important correlations with the cover of three of the four mesotrophic species studied. These two elements showed a highly significant negative correlation with each other and, as stated above, soil $\mathrm{pH}$ strongly correlated with the extractable concentration of both elements. Lowering the extractable concentration of $\mathrm{Mn}$ and increasing the extractable concentration of $\mathrm{Fe}$ via soil acidification therefore appeared to facilitate a reduction in some of the species undesirable in heathland restoration.

\section{DISCUSSION}

The use of soil stripping in addition to elemental sulphur application had little discernible effect on soil chemistry as there were no consistent differences between the sites subject to soil stripping and then sulphur application and sulphur application only. Hence, the application of this expensive technique, which can potentially damage archaeological remains and poses a problem of what to do with the stripped soil, is an unnecessary addition to sulphur application. However, treatment with elemental sulphur reclaimed from the oil refinery had a profound effect on soil chemical properties. In accordance with the findings of other work $[10,17,18,27]$, soil $\mathrm{pH}$ was significantly reduced by sulphur treatment, from 5.94 in the untreated control site to between 4.13 and 4.95 in the sulphur treated soils.

Thus, all sulphur amended soils exhibited soil pH values below the nearby heath. Reclaimed sulphur therefore has a similar efficacy as more expensive and refined sulphur products. Sourcing sulphur from nearby refineries may lower the cost further and this type of crudely processed sulphur results in a wide variety of sulphur particles/granules. The greatly differing surface areas that result should ensure a slow oxidation of the sulphur over many years and in turn, long-term modification of soil chemistry.

Concurrent with the decrease in $\mathrm{pH}$, there was a significant decrease in the extractable concentration of the base cations $\mathrm{Ca}, \mathrm{Mg}$ and $\mathrm{K}$, evidenced by all 3 elements being strongly correlated with soil $\mathrm{pH}$. A reduction in $\mathrm{Ca}$ and $\mathrm{Mg}$ levels is a common effect of soil acidification, including when sulphur application is made, but effects on $\mathrm{K}$ are more varied and changes in extractable $\mathrm{K}$ are not always found [10]. A further typical effect of falling $\mathrm{pH}$, particularly when the $\mathrm{pH}$ falls below $\mathrm{pH} 5.5$, is the increased extractability/solubility of the potentially phytotoxic elements $\mathrm{Al}$ and $\mathrm{Mn}[26,28]$. In the present study, $\mathrm{Mn}$ availability increased with $\mathrm{pH}$ rather than fell, whilst that of Al showed no relationship to soil $\mathrm{pH}$. However, a weak relationship between soil $\mathrm{pH}$ and extractable $\mathrm{Al}$ concentration in the upper horizons of podzolic soils has been reported by other workers $[27,29,30]$ and a more typical negative correlation between $\mathrm{pH}$ and $\mathrm{Al}$ mobility occurs deeper in the profile $[29,30]$, beyond the zone influenced by sulphur application [27]. The reason for the positive relationship between $\mathrm{Mn}$ availability and soil $\mathrm{pH}$ found in the present study was not known, but Mn behaviour is complex and depends on factors other than $\mathrm{pH}$ (particularly Eh) [28]. The relatively high extractable concentration of $\mathrm{Mn}$ in the target heath and untreated control site and low extractable concentration in the sites treated with sulphur suggests that leaching of $\mathrm{Mn}$ from the upper horizons after mobilisation by decreased $\mathrm{pH}$ and/or increased $\mathrm{SO}_{4}{ }^{2-}$ concentration may have occurred.

Soil from the target heath had a very low available $\mathrm{PO}_{4}{ }^{3-}$ concentration compared to the sites treated with sulphur. Indeed, sulphur increased the availability of $\mathrm{PO}_{4}{ }^{3-}$ compared to the control site and availability increased with decreasing soil $\mathrm{pH}$. Sulphur application has been shown to increase $P$ availability in heathland restoration [18] and this reflects the relationship between soil $\mathrm{pH}$ and the $\mathrm{P}$ concentration in the soil solution [31]. Fe concentration in the soil solution also increases with decreasing $\mathrm{pH}$ [31] 
and this is confirmed by the findings of the present study. However, no change in $\mathrm{Fe}$ availability was found by Diaz et al. [18] in response to the application of sulphur for restoration purposes, suggesting that this is not a predictable effect.

Elemental sulphur was successful in reestablishing two key heathland species, $E$. cinerea and $C$. vulgaris. Cover of both species responded most strongly to an increase in the acidity of the soil. Although the other measured chemical parameters of the soil were heavily influenced by the change in soil $\mathrm{pH}$, both species additionally appeared to respond positively to a reduction in availability of base cations. The most abundant mesotrophic grass species in the control site was $A$. capillaris. Control of this species is key to the successful restoration of heathland species such as $E$. cinerea and $C$. vulgaris as they are poor competitors compared to such grasses. Elemental sulphur treatment significantly reduced $A$. capillaris cover, but did not eliminate this species entirely. Agrostis capillaris cover was positively correlated with soil $\mathrm{pH}$ and $\mathrm{Mn}$ availability and negatively correlated with $\mathrm{Fe}$ and $\mathrm{Al}$ availability. Direct toxicity caused by $\mathrm{H}^{+}$ions and the release of $\mathrm{Al}$ into available and therefore toxic forms are major causes of phytotoxicity in acidic soil [32]. The relatively weak negative relationship between $A$. capillaris and the extractable $\mathrm{Al}$ concentration may partially reflect stress caused by $\mathrm{Al}$ availability. However, Al was not strongly mobilised and the main driver of changes in A. capillaris cover over the site as a whole appeared to be due to decreased soil $\mathrm{pH}$.

The results for site $A$ imply another mechanism may have contributed to a decrease in cover of undesirable plant species. Agrostis capillaris cover was lowest in site $A$, as was the cover of the other three main mesotrophic plant species. With the exception of $A$. capillaris, a change in soil $\mathrm{pH}$ was not correlated with a change in mesotrophic plant abundance, hence the suggestion that another mechanism may be responsible for the low plant cover observed in site A. An examination of the soil chemical parameters from this site shows that it had the highest concentration of extractable $\mathrm{Fe}$ and the lowest concentration of extractable Mn. Furthermore, correlations between plant cover and $\mathrm{Mn}$ and $\mathrm{Fe}$ concentrations over all the sites indicated that the extractable concentration of these two elements could possibly influence the cover of mesotrophic species. $\mathrm{Mn}$ is an essential nutrient required by plants for use in redox systems and lignin synthesis [33]. Both $\mathrm{Mn}$ and Fe are acquired by plants via active transport systems involving Natural Resistance Associated Macrophage Protein 1 (NRAMP1) [34] and Zinc RegulatedVIron Regulated Protein (ZIP) family members [35]. Shared uptake pathways can potentially lead to competition for the transporter protein and Korshunova et al. [35] demonstrated that $\mathrm{Fe}^{2+}$ can compete with $\mathrm{Mn}^{2+}$ for the ZIP transporter IRT 1, thereby decreasing $\mathrm{Mn}^{2+}$ uptake by cells. In addition, Vlamis \& Williams [36] demonstrated that increased exposure to Fe can reduce the $\mathrm{Mn}$ content at the tissue level. Therefore, Mn deficiency induced by low $\mathrm{Mn}$ in combination with a high availability of Fe may have contributed to vegetation change, especially in site A.

\section{CONCLUSION}

Treatment of soil with elemental sulphur reclaimed from the oil refinery process provided suitable conditions for the control of competitive mesotrophic plant species and the establishment of heathland species. This reflected changes in the soil chemistry that were consistent with the effects of sulphur processed into fertiliser. The cost of sulphur-fertiliser is between 2-5 times higher than the commodity price of sulphur and so a considerable saving can be made by using sulphur from refineries. The present study has also demonstrated that the effort of stripping the surface soil away has little additional effect on soil chemistry over and above that achieved by sulphur application alone. The present study has therefore demonstrated the most economical method of amending soil chemistry to facilitate heath recreation is to use elemental sulphur obtained from refineries without further processing or soil treatment. Furthermore, in addition to inducing phytotoxicity through increased availability of toxic cations and concurrent reduction in the availability of base cations, the present study has indicated that elemental sulphur application may alter soil chemistry in ways that further stress undesirable plant species by inducing Mn deficiency.

\section{ACKNOWLEDGEMENTS}

We thank the National Trust for access to the Trehill Farm, Beverley Analytical Laboratories for the analysis of soil samples and the students namely Messrs Saffra Curtis, Katriona Macintyre, Rosie Nicoll, Thomas Wilsenham and Kevin 
Wood for their outstanding help in site data collection. We also thank three anonymous reviewers for feedback that enabled us to improve our paper

\section{COMPETING INTERESTS}

Authors have declared that no competing interests exist.

\section{REFERENCES}

1. Loidi J, Biurrun I, Campos JA, García-Mijangos I, Herrera M. A biogeographical analysis of the European Atlantic lowland heathlands. Journal of Vegetation Science. 2010;21(5):832-842.

2. Gimingham $\mathrm{CH}$. Lowland heaths of West Europe: Management for conservation. Phytocoenologia. 1994;24:615-626.

3. Webb NR. The traditional management of European heaths. Journal of Applied Ecology. 1998;35(6):987-990.

4. Rose RJ, Webb NR, Clarke RT, Traynor $\mathrm{CH}$. Changes on the heathlands in Dorset, England, between 1987 and 1996. Biological Conservation. 2000;93(1):117125.

5. García RR, Fraser MD, Celaya R, Ferreira LMM, García U, Osoro K. Grazing land management and biodiversity in the Atlantic European heathlands: A review. Agroforestry Systems. 2013;87(1):9-43.

6. Fagúndez J. Heathlands confronting global change: drivers of biodiversity loss from past to future scenarios. Annals of Botany. 2013;111(2):151-172.

7. Marrs $\mathrm{RH}$. Techniques for reducing soil fertility for nature conservation purposes: A review in relation to research at Roper's Heath, Suffolk, England. Biological Conservation. 1985;34(4):307-332.

8. Aerts $R$, Huiszoon $A$, van Oostrum JHA, van de Vijver CADM, Willems JH. The potential for heathland restoration on formerly arable land at a site in Drenthe, The Netherlands. Journal of Applied Ecology. 1995;32(4):827-835.

9. Lawson CS, Ford MA, Mitchley J, Warren JM. The establishment of heathland vegetation on ex-arable land: The response of Calluna vulgaris to soil acidification. Biological Conservation. 2004;116(3):09-416.

10. Tibbett $\mathrm{M}$, Diaz $A$. Are sulphurous soil amendments $\left(\mathrm{S}^{\mathrm{O}}, \mathrm{Fe}(\mathrm{II}) \mathrm{SO}_{4}, \mathrm{FE}(\mathrm{III}) \mathrm{SO}_{4}\right)$ an effective tool in the restoration of heathland and acid grassland after four decades of rock phosphate fertilization? Restoration Ecology. 2005;13(1):83-91.

11. Pywell RF, Webb NR, Putwain PD. Soil fertility and its implications for the restoration of heathland on farmland in southern Britain. Biological Conservation. 1994;70(2):169-181.

12. Marrs RH, Snow CSR, Owen KM, Evans $\mathrm{CE}$. Heathland and acid grassland creation on arable soils at Minsmere: Identification of potential problems and a test of cropping to impoverish soils. Biological Conservation. 1998;85(1-2):69-82.

13. Allison M, Ausden M. Successful use of topsoil removal and soil amelioration to create heathland vegetation. Biological Conservation. 2004;120(2):221-228.

14. Dorland E, Van Den Berg LJL, Van De Berg AJ, et al. The effects of sod cutting and additional liming on potential net nitrification in heathland soils. Plant and Soil. 2004;265:267-277.

15. Dunsford SJ, Free AJ, Davy AJ. Acidifying peat as an aid to the reconstruction of lowland heath on arable soil: a site experiment. Journal of Applied Ecology. 1998;35(5):660-672.

16. Owen KM, Marrs RH. The use of mixtures of sulphur and bracken litter to reduce $\mathrm{pH}$ of former arable soils and control ruderal species. Restoration Ecology. 2001;9(94): 397-409.

17. Owen KM, Marrs RH, Snow CSR, Evans CE. Soil acidification-the use of sulphur and acidic plant materials to acidify arable soils for the recreation of heathland and acidic grassland at Minsmere, UK. Biological Conservation. 1999;87(1):105121.

18. Diaz A, Green ID, Tibbett M. Re-creation of heathland on improved pasture using topsoil removal and sulphur amendments: edaphic drivers and impacts on ericoid mycorrhizas. Biological Conservation. 2008;141:1628-1635.

19. Hayes MJ, Spiridonova IA. Creation of Coastal heathland from Agricultural Land CCW Science report No. 868. Bangor, Wales: Countryside Council for Wales; 2009.

20. Bråkenhielm S, Liu Q. Comparison of field methods in vegetation monitoring. Water Air and Soil Pollution. 1995;79:75-87.

21. MAFF (Ministry of Agriculture Fisheries \& Food), Agriculture Development and Advisory Service Reference Book 427. The 
Analysis of Agricultural Materials. London, UK: HMSO; 1986.

22. McLean EO. Aluminium. In: Methods of Soil Analysis: Part 2 Chemical and Microbiological Properties. Ed. Black CA, Evans DD, White JL, Ensminger LE, Clark FE, Eds. Madison, Wis, USA: American Society of Agronomy. 1965;978-998.

23. Knights JS, Zhao FJ, McGrath SP, Magan N. Long term effects of land use and fertiliser treatments on sulphur transformations in soils from the Broadbalk experiment. Soil Biology and Biochemistry. 2001;33(12-13):1797-1804.

24. Olsen SR, Cole CV, Watanbe FS, Dean LA. Estimation of Available Phosphorous in Soil by Extraction with Sodium Bicarbonate. Washington DC, USA: United States Department of Agriculture: 1954.

25. Murphy J, Riley JP. A modified single solution method for the determination of phosphate in natural waters. Analytica Chimica Acta. 1962;27:31-36.

26. Foy CD, Chaney RL, White MC. The physiology of metal toxicity in plants. Annual Review of Plant Physiology. 1978;29:511-566.

27. Green I, Stockdale J, Tibbett M, Diaz A. Heathland restoration on former agricultural land: Effects of artificial acidification on the availability and uptake of toxic metal cations. Water Air and Soil Pollution. 2007;178:287-295.

28. Kabata-Pendias $A$, Pendias $H$. Trace elements in soils and plants. 3rd edition. Boca Ranton, USA: CRC Press; 2001.

29. Park SJ, Burt TP. The distribution of solute processes on an acid hill-slope and the delivery of solutes to a stream. II.
Exchangeable $\mathrm{Al}^{+}$. Earth Surface Landforms. 1999;24:851-865.

30. Van Hees $P$, Lundström $U$, Danielsson $R$, Nyberg L. Controlling mechanisms of Aluminium in soil solution - An evaluation of 180 podzolic forest soils. Chemosphere. 2001;45:1091-1101.

31. Tyler G, Olsson T. Concentrations of 60 elements in the soil solution as related to the soil acidity. European Journal of Soil Science. 2001;52(1):151-165.

32. Kinraide TB. Toxicity factors in acidic forest soils: attempts to evaluate separately the toxic effects of excessive $\mathrm{Al}^{3+}$ and $\mathrm{H}^{+}$and insufficient $\mathrm{Ca}^{2+}$ and $\mathrm{Mg}^{2+}$ upon root elongation. European Journal of Soil Science. 2003;54:323-333.

33. Broadley M, Brown P, Cakmak I, Rengel Z, Zhao F. Function of nutrient: Micronutrients. In: Marschner, P. (ed.) Marschner's Mineral Nutrition of Higher Plants 3rd ed. Waltham, USA: Academic Press. 2012;191-248.

34. Cailliatte R, Schikora A, Briat JF, Mari S, Curi, C. High-affinity manganese uptake by the metal transporter NRAMP1 is essential for Arabidopsis growth in low manganese conditions. The Plant Cell. 2010;22:904917.

35. Korshunova YO, Eide D, Clark WG, Guerinot ML, Pakrasi HB. The IRT1 protein from Arabidopsis thaliana is a metal transporter with a broad substrate range. Plant Molecular Biology. 1999;40:37-44.

36. Vlamis J, Williams DE, Ion DE. Competition in manganese uptake by barley plants. Plant Physiology. 1962; 37(5):650-655.

(c) 2015 Green et al.; This is an Open Access article distributed under the terms of the Creative Commons Attribution License (http://creativecommons.org/licenses/by/4.0), which permits unrestricted use, distribution, and reproduction in any medium, provided the original work is properly cited.

Peer-review history:

The peer review history for this paper can be accessed here: http://www.sciencedomain.org/review-history.php?iid=957\&id=24\&aid=8531 